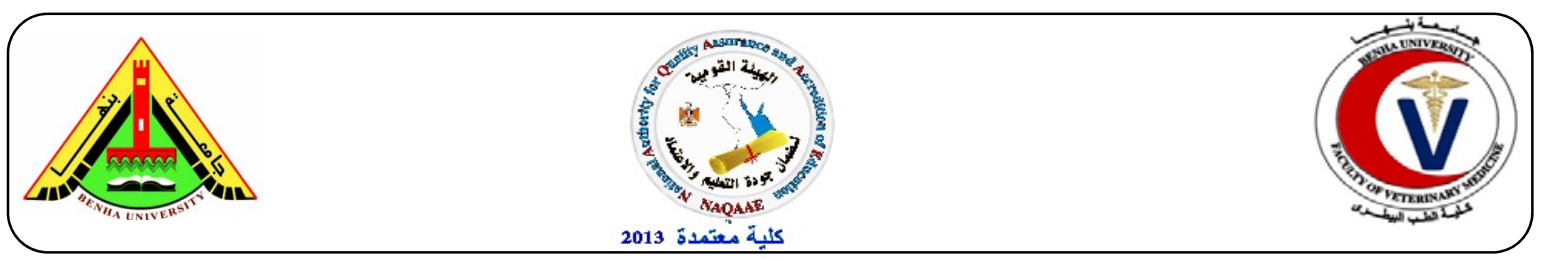

\title{
Molecular characterization of Quinolones and $\beta$-Lactams Resistant Salmonella Serovars Determinants in Diarrheic Calves, lambs and goats-kids in the Middle of Nile Delta, Egypt
}

\author{
Ashraf A. Abd El- Twab ${ }^{1}$, Fatma I. El-Hofy ${ }^{1}$, Amira Mohamed Rizk ${ }^{1}$ \\ ${ }^{I}$ Department of Bacteriology, Immunology and Mycology, Faculty of Veterinary Medicine, Moshtohor, \\ Benha University. Amira.Rizk01@,fvtm.bu.edu.eg
}

\section{A B S T R A C T}

A total of (236 swabs) fecal samples from El-Menofiya and El-Kalubia Governorates, as sporadic cases of were subjected to bacteriological, biochemical, serotyping, sensitivity testing and PCR detection of resistance genes for $\beta$-Lactames and Quinolones. Ten isolates of Salmonella species were identified, as 7 isolates $(4.7 \%)$ from calves (Salmonella Typhimurium, Salmonella Enteritidis, Salmonella saintpaul, Salmonella Langeveld and Salmonella Havana), 2 isolates (3.6\%) from lambs (Salmonella Typhimurium, Salmonella Bardo) and one isolate (3.3\%) from goat-kids (Salmonella Enteritidis) Salmonella isolates sensitivity to $\beta$-lacatmes was $0.00 \%$ for ampicillin, penicillin $G$, piperacillin, cephalexin, cefoxitin, ampicillin-sulbactam, ceftazidime, $10 \%$ for ceftriaxone and $20 \%$ for amoxicillinclavulanic acid, increased to $60 \%$ and $100 \%$ for aztreonam, imipenem respectively. Susceptibility of isolates to quinolones were $10 \%$ for ciprofluxacin, $20 \%$ to nalidixic acid, and $100 \%$ for each of norfloxacin and levofloxacin. PCR study showed beta-lactamase encoding gene, bla (TEM-1), was identified in $90 \%$ and the extended-spectrum beta-lactamase, (CIT) in $20 \%$ while bla (SHV) and acc in $80 \%$ of isolates. The detection was $50 \%, 40 \%$, and $0.00 \%$ for FOX, MOX, and bla (OXA-1) genes, respectively. Plasmid-mediated quinolone resistance, $q n r \mathrm{~B}, q n r \mathrm{~S}$ were detected in $80 \%$ while aac $\left(6^{\prime}\right)$ $\mathrm{Ib}$-cr, was only in $50 \%$ of the isolates. Results showed a high incidence of $\beta$-lacatmase than quinolones resistance genes and higher isolate susceptibility to quinolone than to $\beta$-lacatmes which indicates higher efficacy and validity of quinolones. Results indicates quinolones LEV and NOR in addition to $\beta$ lacatmes imipenem are the drugs of choice for suspected salmonella cases.

Key words: Diarrhea, Calves, Salmonella, $\beta$-lacatmes, Quinolones

(http://www.bvmj.bu.edu.eg)

(BVMJ-30(1): 171-182, 2016)

\section{INTRODUCTION}

Diarrhea is an important cause of morbidity and mortality in young calves (Constable, 2004). Especial attention was poorly undertaken to study the national epidemiology and risk factors of specific etiology of neonatal calf diarrhea in Egypt (El-Khodery and Osman, 2008). Calf salmonella infection can cause a considerable economic loss due to mortality and poor growth of infected animals in addition to risk of causative microorganism transmission to humans either through food chain or direct animal contact (Mohamed et al., 2011). Mortality rates attributable to Salmonella infection are particularly high in young animals, which also generally require the greatest amount of treatment (Hoelzer et al., 2011). The distribution of Salmonella serotypes among cattle varies greatly over time, and differs among geographic regions, age groups, clinical manifestation, and production systems (Animal and Plant Health Inspection Service 2006). Salmonellosis is a major cause of human foodborne illness in Egypt and its infections concern is to be increased 
considering the emergence and increased prevalence of multiantibiotic resistant strains (Davis et al., 1999). Salmonella is a primary etiological agent of infectious diarrhea and represents an important zoonotic pathogen worldwide (Hoelzer et al., 2010). A considerable number of serotypes frequently isolated from humans have been isolated from sick or clinically healthy cattle (Hoelzer et al., 2011). The efficacy of many antimicrobials drugs for treating clinical cases is decreasing as more antimicrobial resistant Salmonella subtypes emerge (Angulo et al., 2000 and Winokur et al., 2000). The emergence and spread of antimicrobial resistant Salmonella strains, particularly those that are resistant to multiple antimicrobials (multi-drug resistant [MDR] Salmonella) is thus a major public health concern (CDC, 2009). In its report at 2013 CDC showed that Drug resistance in Salmonella Typhi has jumped significantly from about $20 \%$ in 1999 to more than $70 \%$ in 2011 (CDC, 2013). The use of antimicrobial agents for growth promotion and feed efficiency is not well monitored and thus in most cases it undergoes miss-use in Egypt. Farmers normally use antimicrobials to treat sick animals with high doses and using their own experience without veterinary prescription, supervision and laboratory diagnosis. This imposes a selective pressure for the emergence and dissemination of antimicrobial-resistant bacteria including animal and humans pathogens (Van and Stobberingh 1999). There are geographical and time-different regimes of antibiotic use for growth promotion, prophylactic or treatment in different region in Egypt. Given the increasing prevalence of Salmonella isolates resistant to antibiotics, necessitates the investigation over different geographical region and continuous periodical search for the prevalence of newly emerged drug-resistant salmonella strains and their MDR determinants. This study aimed to characterize the prevalence, serotypes of Quinolones and $\beta$-Lactames resistant salmonella serovars determinants in diarrheic calves, lambs and goat kids in the Middle of Nile Delta, Egypt.

\section{MATERIAL AND METHODS}

\subsection{Samples Collection:}

A Total of 236 fecal swabs were collected from diarrheic calves (150 cases), lamb (55cases) goat kids (31cases) as sporadic cases presented in Governmental Veterinary Clinics in El-Menofiya and ElKalubia Governorates, Middle-Delta, Egypt

\subsection{Isolation and Identification of salmonella:}

The procedures for isolation of Salmonella from animal faces were according to (ISO6579: 2002 standard). Swabs were weighed and suspended in buffered peptone water (1:10 dilution) then incubated at $37^{\circ} \mathrm{C}(16-$ 20 hours). Then Buffered peptone water $(0.1 \mathrm{ml})$ was transferred with a pipette into a tube containing $(10 \mathrm{ml})$ of RappaportVassiliadis soy peptone (RVS) broth and incubated at $42^{\circ} \mathrm{C}$ (20-24 hours). After that, a loopfull of RVS broth was inoculated and streaked separately onto selective agar plates as Xylose Lysine Desoxycholate (XLD) agar, Brilliant Green agar ( BGA), MacConkey's agar and SalmonellaShigella (S-S) agar plates then incubated at $37^{\circ} \mathrm{C}$ for $24-48 \mathrm{~h}$. Typical colonies of Salmonella on XLD agar were pale pink with black center. On Brilliant Green agar appear as red colonies with a reddening of the media, on Salmonella-Shigella (S-S) agar salmonella colonies appear pale color with or without black centers and on MacConkey's agar appear pale, colorless smooth and transparent. Smears from the suspected Salmonella colonies were stained with Gram's stain and microscopically examined. Suspected colonies were identified as Salmonella spp. based on their colony morphology on selective media, and the biochemical testing using TSI agar, Urea agar, L-lysine decarboxylase, Voges Proskauer, Methyl red tests, Simmons citrate and Indole tests (Edwards and Ewing, 1986). Also, Salmonella spp. were 
confirmed biochemically by using API 20E system (BioMérieux, Marcy-l'Étoile, France). Finally Salmonella isolates were serotyped based on slide agglutination for $\mathrm{O}$ and $\mathrm{H}$ antigens according to KauffmannWhite (1974) and using the antisera from (Mast Salmonella diagnostic antisera) (UK).

\subsection{Antimicrobial sensitivity:}

The antimicrobial sensitivity phenotypes of Salmonella were determined by agar disc diffusion method as described by Finegold and Martin (1982), and according to the guidelines of the Clinical and Laboratory Standards Institute (CLSI, 2014), using antibiotic disc from Oxoid (Thermo Fisher Scientific, Inc. (NYSE: TMO, UK). The discs used were ampicillin (AM) $(10 \mu \mathrm{g})$, penicillin $\mathrm{G}(\mathrm{P})(10 \mu \mathrm{g})$, piperacillin $\mathrm{PRL}$ $(100 \mu \mathrm{g})$, cephalexin CL $(30 \mu \mathrm{g})$, cefoxitin FOX $(30 \mu \mathrm{g})$, ceftazidime CAZ $(30 \mu \mathrm{g})$, ceftriaxone CRO $(30 \mu \mathrm{g})$, aztreonam ACM (30 $\mu \mathrm{g})$, imipenem IPm $(10 \mu \mathrm{g})$, amoxicillin-clavulanic acid AMC $(30 \mu \mathrm{g})$, ampicillin-sulbactam SAM $(20 \mu \mathrm{g})$, nalidixic acid NA $(30 \mu \mathrm{g})$, norfloxacin NOR $(10 \mu \mathrm{g}), \quad$ ciprofloxacin $\mathrm{CIP} \quad(5 \mu \mathrm{g})$, levofloxacin LEV $(5 \mu \mathrm{g})$ (Oxid,UK).

\subsection{Bacterial DNA preparation for PCR:}

Bacterial culture DNA was extracted using the (QIAamp DNA extraction mini kit) (QIAGEN. Duesseldorf, Germany, (Egypt branch) according to the mini kit instructions $(200 \mu \mathrm{l})$ of an overnight bacterial culture was mixed with $200 \mu \mathrm{l}$ buffer plus $20 \mu \mathrm{l}$ QIAGEN protease in 1.5 $\mathrm{ml}$ tube, mixture was incubated at $56^{\circ} \mathrm{C}$ for $10 \mathrm{~min}$, then $200 \mu \mathrm{l}$ ethanol (96\%) were added, vortexing for 15 seconds, applied to the QIAamp mini spin column, centrifugated at $8000 \mathrm{rpm}$ for $1 \mathrm{~min}$, washed two time with washing buffer and DNA was eluted from the column with $150 \mu$ buffer AE elution buffer.

\subsection{Amplification of Antibiotic Resistant genes in salmonella serovars:}

PCR mixture was prepared according to Emerald Amp GT PCR mastermix (Takara, Co., Japan). Code No. RR310A kit: In PCR tube a $6 \mu 1$ bacterial DNA template, $12.5 \mu \mathrm{l}$ Emerald Amp GT PCR master mix (2x premix), $1 \mu 1$ of forward and reverse primers $(20 \mathrm{pmol})$ and $4.5 \mu \mathrm{l} \mathrm{PCR}$ grade water to bring total volume to $25 \mu \mathrm{l}$. The amplification condition was primary denaturation cycle at $94^{\circ} \mathrm{C}$ for $5 \mathrm{~min}$ followed by 35 cycle of $94^{\circ} \mathrm{C}$ for $30 \mathrm{sec}$, $53^{\circ} \mathrm{C}$ for $45 \mathrm{sec}$ and $72^{\circ} \mathrm{C}$ for $45 \mathrm{sec}$ followed by one final extension cycle at $72^{\circ} \mathrm{C}$ for $10 \mathrm{~min}$ using the primers sequence and amplification conditions listed in table (1) for quinolone resistance genes and table (2) for $\beta$-lactamase.

\section{3. RESULTS}

A total of 236 fecal samples from ruminants (150 from calves, 55 from lambs and 31 from goats-kids) were examined for the presence of Salmonella species. Cultivation, isolation and identification procedures identified 10 isolates of Salmonella species as 7 isolates $(4.7 \%)$ from calves (Salmonella Typhimurium, Salmonella Enteritidis, Salmonella Saintpaul, Salmonella Langeveld and Salmonella Havana), 2 isolates $(3.6 \%)$ from lambs (Salmonella Typhimurium, Salmonella Bardo) and one isolate $(3.3 \%)$ from goat-kids(Salmonella Enteritidis) (Table 3, 4). All Salmonella isolates showed $(100 \%)$ resistance to ampicillin, pencillin G; cephalexin, cefoxitin, ampicillin-sulbactam, ceftazidime, and $100 \%$ sensitivity to imipenem (Table 5).

None of the tested Salmonella isolates were positive for OXA $\beta$-lactamase resistance gene, While they have some of other $\beta$-lactamase resistance gene (Table 6). All isolates were sensitive to norfloxacin and levofloxacin and negative for qnrA gene but positive for some or all other quinolone resistance genes (Table 7, 8). 
Table (1) primers used for amplification of quinolone resistance genes

\begin{tabular}{|c|c|c|c|}
\hline Primer & Sequence & Product size & Reference \\
\hline$q n r \mathrm{~A}$ & $\begin{array}{l}\text { ATTTCTCACGCCAGGATTTG } \\
\text { GATCGGCAAAGGTTAGGTCA }\end{array}$ & $516 \mathrm{bp}$ & $\begin{array}{l}\text { Robicsek et al., } \\
2006\end{array}$ \\
\hline$q n r \mathrm{~B}$ & $\begin{array}{l}\text { GATCGTGAAAGCCAGAAAGG } \\
\text { ACGATGCCTGGTAGTTGTCC }\end{array}$ & $469 \mathrm{bp}$ & \\
\hline$q n r \mathrm{~S}$ & $\begin{array}{l}\text { ACGACATTCGTCAACTGCAA } \\
\text { TAAATTGGCACCCTGTAGGC }\end{array}$ & $417 \mathrm{bp}$ & \\
\hline$a a c\left(6^{\prime}\right)-I b-c r$ & $\begin{array}{l}\text { CCCGCTTTCTCGTAGCA } \\
\text { TTAGGCATCACTGCGTCTTC }\end{array}$ & $113 \mathrm{bp}$ & Lunn et al., 2010 \\
\hline
\end{tabular}

Table (2) primers used for amplification of $\beta$-lactamase

\begin{tabular}{|c|c|c|c|}
\hline Primer & Sequence & Product size & Reference \\
\hline bla & $\begin{array}{l}\text { ATCAGCAATAAACCAGC } \\
\text { CCCCGAAGAACGTTTTC }\end{array}$ & 516 bp & $\begin{array}{l}\text { Colom et al., } \\
2003\end{array}$ \\
\hline bla SHV $_{\mathrm{SH}}$ & $\begin{array}{l}\text { AGGATTGACTGCCTTTTTG } \\
\text { ATTTGCTGATTTCGCTCG }\end{array}$ & 392 bp & \\
\hline$b_{1}{ }_{1} a_{\mathrm{OXA}-}$ & $\begin{array}{l}\text { TCAACTTTCAAGATCGCA } \\
\text { GTGTGTTTAGAATGGTGA }\end{array}$ & 609 bp & \\
\hline MOX & $\begin{array}{l}\text { GCT GCT CAA GGA GCA CAG GAT } \\
\text { CAC ATT GAC ATA GGT GTG GTG C }\end{array}$ & $520 \mathrm{bp}$ & $\begin{array}{l}\text { Pérez-Pérez } \\
\text { and Hanson, }\end{array}$ \\
\hline CIT & $\begin{array}{l}\text { TGG CCA GAA CTG ACA GGC AAA } \\
\text { TTT CTC CTG AAC GTG GCT GGC }\end{array}$ & 462 bp & 2002 \\
\hline Acc & AAC AGC CTC AGC AGC CGG TTA & 346 bp & \\
\hline FOX & $\begin{array}{l}\text { TTC GCC GCA ATC ATC CCT AGC } \\
\text { AAC ATG GGG TAT CAG GGA GATG } \\
\text { CAA AGC GCG TAA CCG GAT TGG }\end{array}$ & $190 \mathrm{bp}$ & \\
\hline
\end{tabular}

Table (3) Prevalence of Salmonella species in diarrheic calves, lambs and goats kids

\begin{tabular}{lccc}
\hline Animals species & $\begin{array}{c}\text { Number } \\
\text { of cases }\end{array}$ & $\begin{array}{c}\text { Salmonella } \\
\text { positive cases }\end{array}$ & Percentage \\
\hline Calves & 150 & 7 & $4.7 \%$ \\
Lambs & 55 & 2 & $3.6 \%$ \\
Goat kids & 31 & 1 & $3.3 \%$ \\
\hline
\end{tabular}

Table (4) Serotypes of Salmonella isolates from diarrheic calves, lambs and goats kids

\begin{tabular}{|c|c|c|c|c|}
\hline $\begin{array}{l}\text { Animal } \\
\text { species }\end{array}$ & $\begin{array}{l}\text { Isolate } \\
\text { number }\end{array}$ & Serotype & $\begin{array}{l}\text { Serotype \% in all } S . \\
\text { isolates from Calves }\end{array}$ & $\begin{array}{l}\text { Serotype \% in all } \\
\text { S. isolates }\end{array}$ \\
\hline \multirow{8}{*}{ Calves } & 99 & S. Typhimurium & $14.3 \%$ & $20 \%$ \\
\hline & 103 & S. Enteritidis & $14.3 \%$ & $20 \%$ \\
\hline & 62 & S. Saintpaul & & \\
\hline & 73 & S. Saintpaul & $28.6 \%$ & $20 \%$ \\
\hline & 67 & S.Langeveld & & \\
\hline & 96 & S. Langeveld & $28.6 \%$ & $20 \%$ \\
\hline & 133 & S. Havana & $14.3 \%$ & $10 \%$ \\
\hline & & & $\begin{array}{l}\text { Serotype } \% \text { in all } S . \\
\text { isolates. from Ovine }\end{array}$ & \\
\hline \multirow[t]{2}{*}{ Lambs } & 10 & S. Typhimurium & $33 \%$ & \\
\hline & 27 & S. Bardo & $33 \%$ & $10 \%$ \\
\hline Goats kids & 25 & S. Enteritidis & $33 \%$ & \\
\hline
\end{tabular}


Table (5) Sensitivity of the Salmonella Serotypes isolated from diarrheic calves, lambs and goats kids to $\beta$-Lactams

\begin{tabular}{|c|c|c|c|c|c|c|c|c|c|c|c|}
\hline \multirow[t]{2}{*}{ S. Serovars } & \multicolumn{11}{|c|}{ Zone of inhibition due to Antibiotic discs in each Salmonella Serovars } \\
\hline & Am & $\mathrm{P}$ & PRL & CL & FOX & $\begin{array}{c}\text { AM } \\
\text { C }\end{array}$ & SAM & CAZ & $\mathrm{CRO}$ & ATM & IPM \\
\hline S. Typhimurium & $(-) \mathrm{R}$ & $(-) \mathrm{R}$ & $(-) \mathrm{R}$ & $(-) \mathrm{R}$ & $(-) \mathrm{R}$ & $(-) \mathrm{R}$ & $(-) \mathrm{R}$ & $(-) \mathrm{R}$ & (21) I & $(25) \mathrm{S}$ & $(30) \mathrm{S}$ \\
\hline S. Enteritidis & $(9) \mathrm{R}$ & $(-) \mathrm{R}$ & $(18) \mathrm{I}$ & $(8) \mathrm{R}$ & $(-) \mathrm{R}$ & $\begin{array}{c}\text { (19) } \\
\text { S }\end{array}$ & $(-) \mathrm{R}$ & $(-) \mathrm{R}$ & (24)S & (26)S & (32)S \\
\hline S. Saintpaul & $(-) \mathrm{R}$ & $(-) \mathrm{R}$ & $(-) \mathrm{R}$ & $(-) \mathrm{R}$ & $(-) \mathrm{R}$ & $(-) \mathrm{R}$ & $(-) \mathrm{R}$ & $(-) \mathrm{R}$ & $(-) \mathrm{R}$ & $(-) \mathrm{R}$ & (27)S \\
\hline S. Saintpaul & $(-) \mathrm{R}$ & $(-) \mathrm{R}$ & $(-) \mathrm{R}$ & $(-) \mathrm{R}$ & $(-) \mathrm{R}$ & $\begin{array}{c}(10) \\
\mathrm{R}\end{array}$ & $(-) \mathrm{R}$ & $(-) \mathrm{R}$ & $(-) \mathrm{R}$ & $(-) \mathrm{R}$ & (30)S \\
\hline S.Langeveld & $(-) \mathrm{R}$ & $(-) \mathrm{R}$ & $(-) \mathrm{R}$ & $(-) R$ & $(-) \mathrm{R}$ & $\begin{array}{c}\text { (15) } \\
\mathrm{R}\end{array}$ & $(-) \mathrm{R}$ & $(-) \mathrm{R}$ & $(-) \mathrm{R}$ & $(-) \mathrm{R}$ & (30)S \\
\hline S. Langeveld & $(-) \mathrm{R}$ & $(-) \mathrm{R}$ & (18) I & $(-) \mathrm{R}$ & $(-) \mathrm{R}$ & $(-) \mathrm{R}$ & $(-) \mathrm{R}$ & $(-) \mathrm{R}$ & $(-) \mathrm{R}$ & $(-) \mathrm{R}$ & (30)S \\
\hline S. Havana & $(-) \mathrm{R}$ & $(-) \mathrm{R}$ & $(-) \mathrm{R}$ & $(-) \mathrm{R}$ & $(-) \mathrm{R}$ & (9)R & $(-) R$ & $(-) R$ & $(20) \mathrm{I}$ & (22)S & (27)S \\
\hline S. Typhimurium & $(-) \mathrm{R}$ & $(-) \mathrm{R}$ & $(-) \mathrm{R}$ & $(-) \mathrm{R}$ & $(-) \mathrm{R}$ & $\begin{array}{c}\text { (11) } \\
\mathrm{R}\end{array}$ & $(-) \mathrm{R}$ & $(-) \mathrm{R}$ & (17)R & (21)S & (30)S \\
\hline S. Bardo & $(-) \mathrm{R}$ & $(-) \mathrm{R}$ & $(-) \mathrm{R}$ & $(-) \mathrm{R}$ & $(-) \mathrm{R}$ & $(-) \mathrm{R}$ & $(-) \mathrm{R}$ & $(-) \mathrm{R}$ & (22)I & (24)S & (29)S \\
\hline S. Enteritidis & $(6) R$ & $(-) \mathrm{R}$ & $\begin{array}{c}(17) \\
\mathrm{R}\end{array}$ & (6)R & $(-) \mathrm{R}$ & $\begin{array}{c}\text { (19) } \\
\text { S }\end{array}$ & $(-) \mathrm{R}$ & (7)R & (21)I & (25)S & (30)S \\
\hline $\begin{array}{c}\text { Number of } \\
\text { resistant } \\
\text { serovars }\end{array}$ & 10 & 10 & 8 & 10 & 10 & 8 & 10 & 10 & 5 & 4 & 0.00 \\
\hline $\begin{array}{c}\text { Percentage of } \\
\text { resistant } \\
\text { Serovars } \\
\end{array}$ & $\begin{array}{r}100 \\
\%\end{array}$ & $\begin{array}{c}100 \\
\%\end{array}$ & $80 \%$ & $\begin{array}{c}100 \\
\%\end{array}$ & $100 \%$ & $80 \%$ & $100 \%$ & $\begin{array}{c}100 \\
\%\end{array}$ & $50 \%$ & $40 \%$ & 0.00 \\
\hline
\end{tabular}

-Am, ampicillin; P, pencillin G; PRL, piperacillin; CL, cephalexin; FOX, cefoxitin; AMC, amoxicillin-clavulanic acid; SAM, ampicillin- sulbactam; CAZ, ceftazidime; CRO, ceftriaxone; ATM, aztreonam; IPM, imipenem. Number in brackets: size of inhibition zone with mm according to (CLSI 2014). -R: resistant, S: sensitive, I: intermediate.

Table (6) Incidence of B-Lactamase genes in Salmonella isolates detected by PCR

\begin{tabular}{lccccccc}
\hline & \multicolumn{7}{c}{ Genes } \\
S. Serovars & bla $_{\mathrm{TEM}}$ & bla $_{\mathrm{SHV}}$ & bla $_{\mathrm{OXA}-1}$ & MOX & CIT & Acc & FOX \\
\hline S. Typhimurium & + & - & - & - & - & + & - \\
S. Enteritidis & + & + & - & + & - & + & + \\
S. Saintpaul & + & + & - & - & + & - & + \\
S. Saintpaul & + & + & - & - & - & + & - \\
S.Langeveld & + & + & - & - & - & + & - \\
S. Langeveld & + & + & - & - & - & + & - \\
S. Havana & + & + & - & + & + & - & + \\
S. Typhimurium & - & - & - & - & - & + & - \\
S. Bardo & + & + & - & + & - & + & + \\
\hline S. Enteritidis & + & + & - & + & - & + & + \\
\hline
\end{tabular}


Table (7) Sensitivity of the Salmonella Serotypes isolated from diarrheic calves, lambs and goat's kids to quinolones

$$
\text { Antibiotic discs }
$$

S. Serovars

\begin{tabular}{lcccc} 
& NA & NOR & CIP & LEV \\
\hline S. Typhimurium & $(-) \mathrm{R}$ & $(31) \mathrm{S}$ & $(35) \mathrm{S}$ & $(30) \mathrm{S}$ \\
S. Enteritidis & $(7) \mathrm{R}$ & $(21) \mathrm{S}$ & $(25) \mathrm{I}$ & $(23) \mathrm{S}$ \\
S. Saintpaul & $(20) \mathrm{S}$ & $(25) \mathrm{S}$ & $(30) \mathrm{I}$ & $(28) \mathrm{S}$ \\
S. Saintpaul & $(-) \mathrm{R}$ & $(25) \mathrm{S}$ & $(23) \mathrm{I}$ & $(20) \mathrm{S}$ \\
S. Langeveld & $(-) \mathrm{R}$ & $(22) \mathrm{S}$ & $(22) \mathrm{I}$ & $(20) \mathrm{S}$ \\
S. Langeveld & $(19) \mathrm{S}$ & $(27) \mathrm{S}$ & $(24) \mathrm{I}$ & $(20) \mathrm{S}$ \\
S. Havana & $(-) \mathrm{R}$ & $(22) \mathrm{S}$ & $(20) \mathrm{R}$ & $(18) \mathrm{S}$ \\
S. Typhimurium & $(17) \mathrm{I}$ & $(21) \mathrm{S}$ & $(21) \mathrm{I}$ & $(19) \mathrm{S}$ \\
S. Bardo & $(-) \mathrm{R}$ & $(22) \mathrm{S}$ & $(26) \mathrm{I}$ & $(24) \mathrm{S}$ \\
S. Enteritidis & $(-) \mathrm{R}$ & $(24) \mathrm{S}$ & $(27) \mathrm{I}$ & $(24) \mathrm{S}$ \\
$\quad$ Number of & 7 & 0.00 & 1 & $0-00$ \\
$\quad$ resistant & & & & \\
$\quad$ serovars & & & & \\
$\begin{array}{c}\text { Percentage of } \\
\text { resistant Serovars }\end{array}$ & $70 \%$ & 0.00 & $10 \%$ & 0.00
\end{tabular}

nalidixic acid; NOR, norfloxacin; CIP, ciprofloxacin; LEV, levofloxacin. -Number in brackets: size of inhibition zone with mm. according to (CLSI 2014). -R: resistant, S: sensitive, I: intermediate

Table (8) Incidence of quinolone resistance genes in Salmonella isolates detected by PCR

\section{Genes}

S. Serovars

\begin{tabular}{lrrrc} 
& $q n r \mathrm{~A}$ & $q n r \mathrm{~B}$ & $q n r \mathrm{~S}$ & $a a c\left(6^{\prime}\right)-\mathrm{Ib}-\mathrm{cr}$ \\
\hline S. Typhimurium & - & + & + & + \\
S. Enteritidis & - & - & + & - \\
S. Saintpaul & - & + & + & + \\
S. Saintpaul & - & + & + & + \\
S. Langeveld & - & + & + & + \\
S. Langeveld & - & - & + & + \\
S. Havana & - & - & - & - \\
S. Typhimurium & - & + & - & - \\
S. Bardo & - & + & + & - \\
S. Enteritidis & - & + & + & - \\
\hline
\end{tabular}




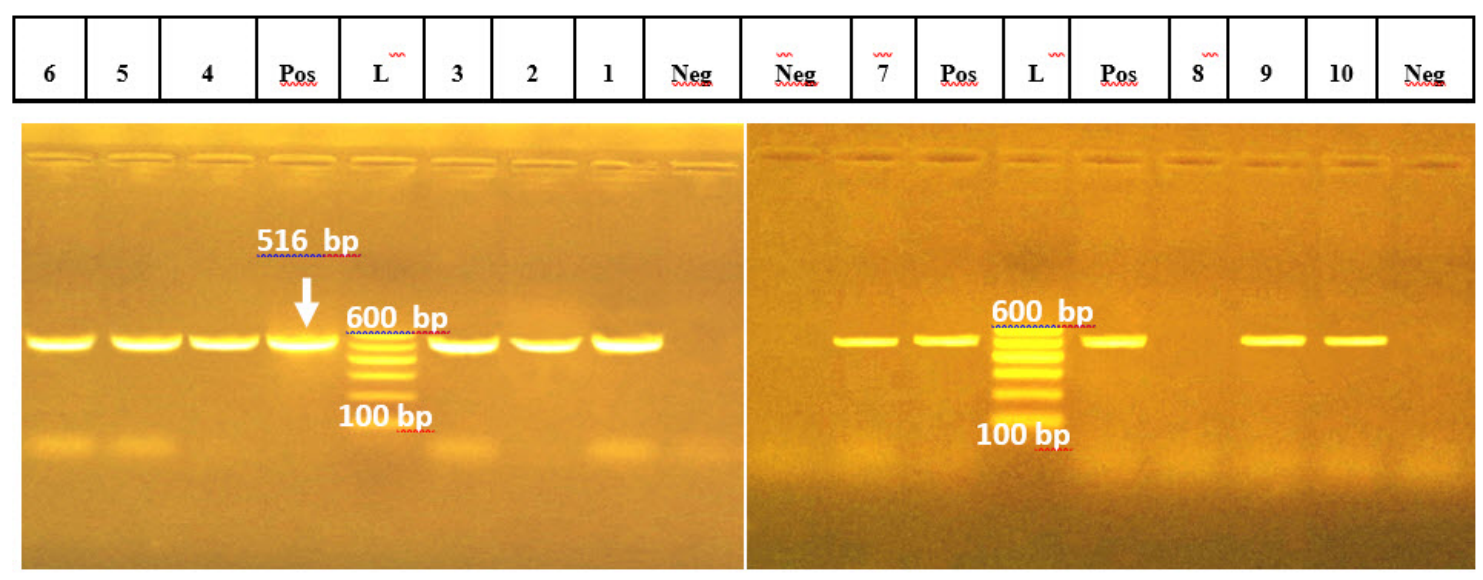

Figure (1):PCR detection of one of the $\beta$-Lactamase genes $\left(\right.$ bla $\left._{T E M}\right)$ in different Salmonella serovars

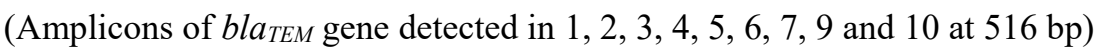
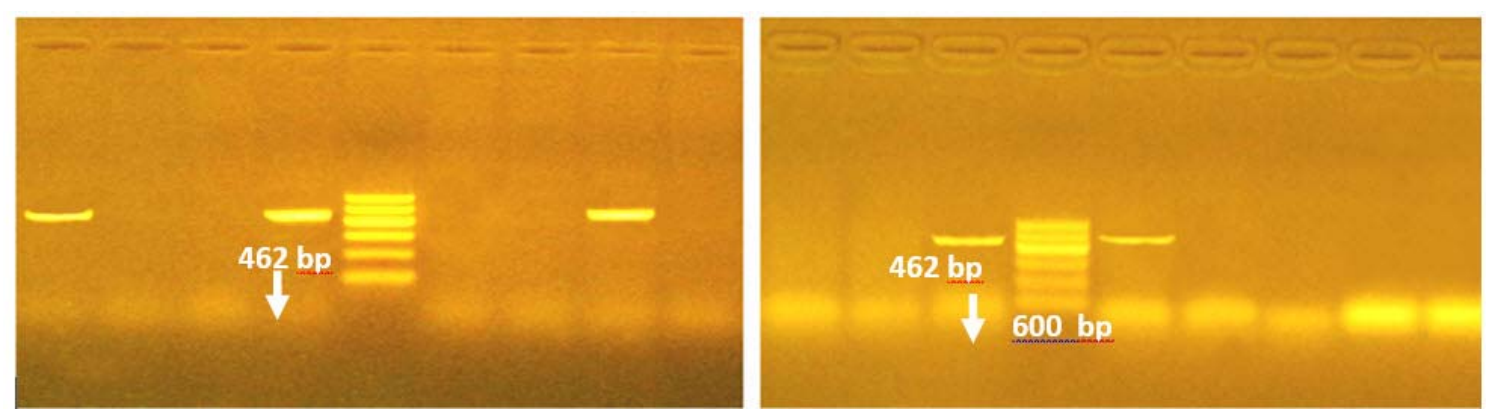

Figure(2): PCR detection of one of B-lactamase gene (CIT) in different salmonella isolates. (Amplicons of CIT gene detected in 1 and 6 at 462 bp). L (DNA ladder), Neg (Negative control), Pos (Positive control), (1-7) Salmonella isolates from Diarrheic calves: 1,3 (S. Saintpaul), 2,4 (S. Langeveld)) ,5 (S. Typhimurium) ,6 (S. Havana), 7 (S. Enteritidis), $(8,10)$ Salmonella isolates from diarrheic lambs :8 (S. Typhimurium), 10 (S. Bardo), 9 (S. Enteritidis) from diarrheic goats kids.
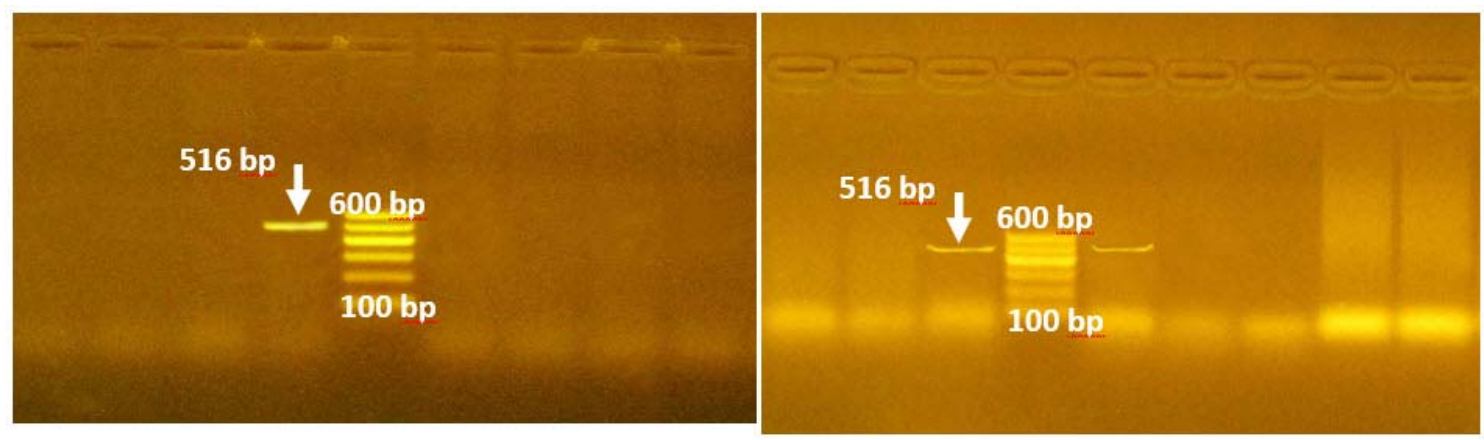

Figure(3):PCR detection of one quinolone resistance genes $(q n r \mathrm{~A})$ in different salmonella isolates (all isolates negative for this gene). 


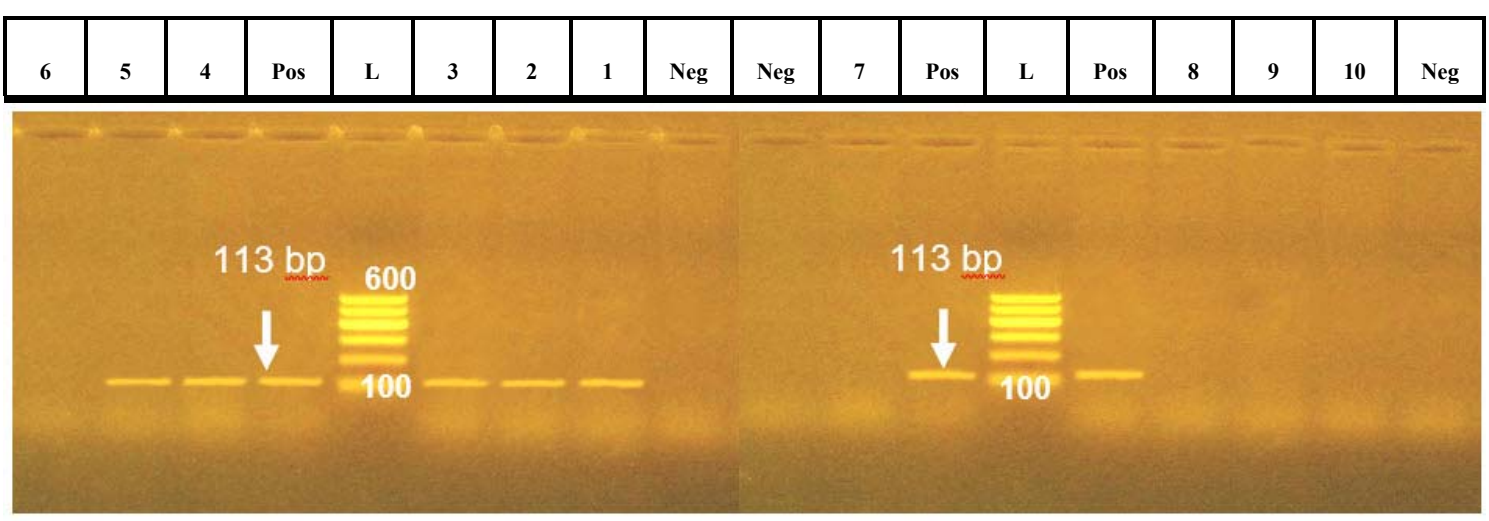

Figure(4): PCR detection of one of the quinolone resistance gene (aac6-Ib-cr) in different Salmonella isolates (Amplicons of $a a c\left(6^{\prime}\right)-I b-c r$ gene detected in 1, 2, 4 and 5 at $113 \mathrm{bp}$ ). L (DNA ladder), Neg (Negative control), Pos (Positive control), (1-7) Salmonella isolates from Diarrheic calves: 1,3 (S. Saintpaul), 2,4 (S. Langeveld)) ,5 (S. Typhimurium) ,6 (S. Havana), 7 (S. Enteritidis), (8, 10) Salmonella isolates from diarrheic lambs :8 (S. Typhimurium), 10 (S. Bardo), 9 (S. Enteritidis) from diarrheic goats kids.

\section{DISCUSSION}

Salmonella causes substantial economic loss resulting from mortality, morbidity and poor growth with hazard of transmitting food poisoning with gastroenteritis to human and represents a serious problem for the food industry (Khan et al., 2007). Salmonella infections continue to be a challenge in Egypt and it is thus important to study the resistance mechanisms to antimicrobial agents in species of this genus and their clinical impact in human and animals. The two main therapeutic alternatives against these organisms are both fluoroquinolones and new $\beta$-lactams, for their bactericidal activity and their excellent pharmacokinetic properties (Piddock 2002). This study aimed to study the prevalence of salmonella species in the sporadic cases of diarrheic calves, lambs and goat kids in the middle of Egypt and to identify their serotypes in addition to determination of their sensitivity or resistant to $\beta$-lactames and Quinolones and to characterizes the determinant of their resistance to these antibiotics.

The results showed the prevalence of salmonella species in sporadic cases of diarrheic calves is about $4.7 \%$ while its prevalence is $3.6 \%$ and $3.3 \%$ in Lamb and goats kids respectively. The result in diarrheic calves is somewhat higher than a previous results showing salmonella prevalence in Egypt a 4.09\% (Younis et al 2009). The higher prevalence encountered in our study may be due to time or regional differences depending on the antibiotics regimes used. As the administration of therapeutic and sub-therapeutic antimicrobials to animals may determine the emergence and dissemination of antibiotic-resistant bacteria (Piddock 2000). Salmonella prevalence in lambs and goat kids in this study differs from that reported from a study conducted on lambs in Behera, Province, Egypt that was 5.26\% (Mohammed et al., 2014). This difference may be regional dependent according to environmental condition and antibiotics regimes used in that region. Salmonella was also isolated in higher rate $15 \%$ of lamb diarrhea cases (Ahmed et al. (2010). This may be related to the relative small number of cases collected as multiple fecal samples are required for higher rates of salmonella isolation (Duijkeren et al., 1995).

Serotyping of salmonella isolates showed calves diarrhea was mostly caused by $S$. Saintpaul 28.6\% and S. Langeveld 28.6\% while the percentage was only $14.3 \%$ for $S$. Typhimurium, S. Entritidis and S. Havana. 
This prevalence of salmonella serotypes that caused calves diarrhea is completely differs than that was found in diarrheic calves in other region in Egypt that was mainly $S$. Typhimurium, S. Enteritidis (Younis et al., 2009). This may be explained by the different antibiotics regimes in different region. Indeed, selective pressure favors the emergence of antimicrobial resistance pathogens such as Salmonella, which is frequently harbored in the animal intestinal tract (Aarestrup, 2000). This may necessitate different antibacterial systems in different region to treat salmonella infection based on screening of the isolates in each specified region.

Susceptibility of different salmonella to members of $\beta$-lactames antibiotics showed that most isolates are resistant to all $\beta$ lactames except $10 \%, 60 \%$ and $100 \%$ of the isolates were sensitive to ceftriaxone, aztreonam and Imipenem respectively. The wide range of resistant salmonella isolates to $\beta$-lactames in this study corresponds well to the diversity of $\beta$-lactamase genes detected by PCR in these isolates. The greatest variation in $\beta$-lactames resistance and $\beta$-lactamase genes was seen among diagnostic $E$. coli isolates from cattle and pigs, which according to DANMAP 2002 also are the animal groups that are treated with the most different $\beta$-lactames antibiotics (DANMAP 2003). However, the blaTEM-1 gene was detected in all isolates in current study while it was detected in about $81 \%$ in Denmark and $77 \%$ in Spain (Olesen et al., 2004). In this study the high rate of resistant isolates and high expression of the blaTEM-1 gene may reflect the uncontrolled and misuse of the $\beta$-lactames in Egypt that has been used in the past period and their invalidity for combating salmonella at least in the regions of sampling. Majority of isolates expressed blashv and Acc genes whereas none of them produced blaoxa $\beta$ lactamases, and few 20\%, 40\% and 50\% produced CIT, MOX and FOX $\beta$ lactamases respectively. This may explain the sensitivity of some isolates to $\beta$ lactamases genes.

Mechanisms of resistance to quinolones in Salmonella include target gene mutations, active efflux, and decreased outer membrane permeability (Axel and Elisabeth, 2001). Quinolone resistant in Egyptian typhoid fever patient has been reported to be rising from $0.00 \%$ at 1993 (Abdel-Ghafar et al.,1994) to 15\% in 2013 (Fatma et al.,2014) . In this study on diarrheic calves, lambs and goats kids we found $70 \%$ of the isolates were resistant to NA and $10 \%$ were resistant to CIP while 0.0 $\%$ were resistant to both LEV and NOR. In contrary to our results, it was found that $7.5 \%$ of salmonella isolates from Egyptian typhoid fever patient were resistant to both NAL and LEV, and 2.5\% were resistant to all three quinolones NAL, NOR, and LEV (Fatma et al., 2014). This discrepancy could be species and/or regional dependent. It is worse mentioning here that the susceptibility of the isolates to CIP was $90 \%$ meanwhile it was only $30 \%$ to NA which indicates the difference between the two antibiotics efficacy. This may contradict the assumption considering nalidixic acid resistance as an indicator for reduced susceptibility to ciprofloxacin (Rahman et al., 2014). The absence of the $q n r \mathrm{~A}$ and $a a c\left(6^{\prime}\right)-I b-c r$ gene from $100 \%$ and $50 \%$ of the isolates respectively may be the key that renders all isolates susceptible to NA and NOR while the presence of the $q n r \mathrm{~B}$ and $q n r \mathrm{~S}$ in the majority of the isolates may be the cause of $70 \%$ and $10 \%$ of the isolates being resistant to NA and CIP respectively. However, the susceptibility of all isolates to quinolone is higher than $\beta$ lactames which make quinolone efficacy and validity for treatment of Salmonella infection is more acceptable than $\beta$ lactames in the region of sampling of this study.

\section{CONCLUSION}

Overall susceptibility of the isolates is higher to quinolone than to $\beta$-lactames. 
This make quinolones efficacy and validity for treatment of Salmonella infection is more acceptable than $\beta$-lactames especially in the region of sampling of this study. These results also indicate quinolones especially NOR and LEV in addition to the $\beta$-lacatmes imipenem are drugs of choice for suspected salmonella cases a note to be considered by Veterinarians and animal breeder in the region of our study.

\section{REFERENCES}

Aarestrup, F.M. 2000. Occurrence, selection and spread of resistance to antimicrobial agents used for growth promotion for food animals in Denmark. APMIS Suppl. 101:1-48.

Abdel-Ghafar, F.A., Ashour, M.S., AbdelLatif, H.K., Kadry, A.A., Atia, A., Fekry, S. 1994. Resistance patterns of clinical isolates of Salmonella and its correlation with plasmid profile. Zagazig J Pharm Sci 3: 51-57.

Ahmed, A., Egwu, G. O., Garba, H. S., Magaji, A.A.2010. Prevalence of bacterial pathogens and serotyping of E. coli isolates from diarrhoeic lambs in Sokoto state, Nigeria. Sokoto J. Vet. Sci. 8: 1/2, 42-45.

Angulo, F.J., Johnson, K.R., Tauxe, R.V., Cohen, M.L. 2000. Origins and on sequences of antimicrobial-resistant non typhoidal Salmonella: implications for the use of fluoroquinolones in food animals. Microb. Drug Resist. 6:77-83.

Animal and Plant Health Inspection Service, United States Department of Agriculture: Report of the Committee on Salmonella, The National Veterinary Services Laboratory Report. 2006 [http://www.usaha.org/ committees/reports/2006/report-sal2006.pdf].

Axel cloeckaert, Elisabeth chaslus-dancla. 2001. Mechanisms of quinolone resistance in Salmonella. Vet. Res. 32: 291-300.
CDC (Centers for Disease Control and Prevention). 2009. Preliminary Food Net data on the incidence of infection with pathogens transmitted commonly through food - 10 states. MMWR Morb Mortal Wkly Rep 59(14):418-422.

CDC, U.S. Department of Health and Human service (Center for Disease control and prevention. ANTIBIOTIC RESISTANCE THREATS in the United States, 2013. http:// www.cdc.gov /drug resistance /pdf/ar-threats-2013508.pdf.

CLSI. 2014.Clinical and Laboratory Standards Institute antimicrobial susceptibility testing standards M100-S24 Performance Standards for Antimicrobial Susceptibility Testing; $\quad$ Twenty- $\quad$ Fourth Informational Supplement 2014. (http://clsi.org/wp-content /uploads /sites/14/2014/12/CLSI_Fall_2014_ Catalog_Web1.pdf).

Colom, K., Pèrez, J., Alonso, R., Fernández-Aranguiz, A.,Lariňo, E., Cisterna, R. 2003.Simple and reliable multiplex PCR assay for detection of blaTEM,blaSHV and blaOXA-1 genes in Enterobacteriaceae. FEMS Microbiology Letters 223: 147-151.

DANMAP. 2002. Use of antimicrobial agents and occurrence of antimicrobial resistance in bacteria from food animals, foods and humans in Denmark. Danish Institute for Food and Veterinary Research, Copenhagen, Denmark.

DANMAP. 2003. Use of antimicrobial agents and occurrence of antimicrobial resistance in bacteria from food animals, foods and humans in Denmark. Danish Institute for Food and Veterinary Research, Copenhagen, Denmark.

Davis, M.A., Hancock, D.D., Besser, T.E. 1999. Changes in antimicrobial resistance among Salmonella enterica 
serovar typhimurium isolates from humans and cattle in the northwestern United States, 1982-1997. Emerg Infect Dis; 5:802-806.

Duijkeren, E., Flemming, C., Van OldruitenborghOosterbaan, M.M. 1995. Diagnosing salmonellosis in horses: culturing of multiple versus single faecal samples. Vet. Quarterly.17: 63-66.

Edwards, P.R., Ewing, W.H. 1986. Edwards and Ewing's identification of Enterobacteriaceae, third ed. Elsevier s Science Publishing Co., Inc., New York.

El-Khodery, S., Osman, S., 2008. Cryptosporidiosis in buffalo calves (Bubalus bubalis): prevalence and potential risk factors. Tropical Animal Health and Production 40, 419-426.

Fatma, O.I., Saleh, 1., Hazem, A., Ahmed, Rasha, M.M., Khairy, Sayed, F. Abdelwahab. 2014. Increased quinolone resistance among typhoid Salmonella isolated from Egyptian patients. J Infect Dev Ctries 8(5):661665.

Finegold, S.M., Com, Martin, W.J. 1982. Diagnostic microbiology.6th Ed, The C.V. Mosby pany, St. Louis, Toronto,London.

Hoelzer Karin, Andrea Isabel Moreno Switt, Martin Wiedmann. 2011. Animal contact as a source of human non-typhoidal salmonellosis. Veterinary Research, 42:34.

Hoelzer, K., Soyer, Y., Rodriguez, L., Cummings, K., McDonough, P., Schoonmaker, D., Root, T., Dumas, N., Warnick, L., Grohn, Y., Wiedmann, M., Baker, K., Besser, T., Hancock, D., Davis, M. 2010. The prevalence of multidrug resistance is higher among bovine than human Salmonella enteric serotype Newport, Typhimurium, and 4, 5, 12: i: isolates in the United States but differs by serotype and geographic region. Appl. Environ. Microbiol., 76(17): 5947 -5959.

ISO 6579. 2002 .4th ed: MicrobiologyGeneral guidance on methods for the detection of Salmonella, International organize for standardization, Geneve, Switzerland.

Kauffman, F.1974. Serological diagnosis of Salmonella species. Kauffman White Scheme, Copenhagn, Denmark.

Khan, A.A., Melvin, C.D., Dagdag, E.B. 2007. Identification and molecular characterization of Salmonella spp. from unpasteurized orange juices and identification of new serotype Salmonella Strain S. enteric serovar. Food Microbiology 24(5):39-43.

Lunn, A.D., Fàbrega, A., SánchezCéspedes, J., Vila, J. 2010. Prevalence of mechanisms decreasing quinolone-susceptibility among Salmonella spp. clinical isolates. International Microbiology. 13:1520.

Mohamed, O., Farid, A., Abaza, A., Faltas, R. 2011. Fecal shedding of nontyphoidal Salmonella species in dairy cattle and their attendants in Alexandria suburbs. J. Am. Sci., 7(9): 623631.

Mohammad, Nasr, Nabil, Bakeer, M., Hassan, A., Hammouda, Alaa, Omar, A. 2014. Epidemiological, Clinical and Bacteriological Studies on Bacterial Lamb Enteritis at Behera Province, Egypt. Alexandria Journal of Veterinary Sciences 43: 8-16.

Olesen, I., Hasman, H., Aarestrup, F.M. 2004. Prevalence of beta-lactamases among ampicillin-resistant Escherichia coli and Salmonella isolated from food animals in Denmark. Microb Drug Resist. Winter;10(4):334-40.

Pérez-Pérez, F.J., Hanson, N.D. 2002. Detection of Plasmid-Mediated AmpC B-Lactamase Genes in Clinical Isolates by Using Multiplex PCR. 
JOURNAL OF CLINICAL MICROBIOLOGY, June 2002, p. 2153-2162.

Piddock, L.J.V.2002.Flouroquinolone resistance in Salmonella serovars isolated from humans and food animals. FEMS Microbiol Rev; 26:316.

Piddock, L.J., White, D.G., Gensberg, K., Pumbwe, L., Griggs, D.J. 2000. Evidence for an efflux pump mediating multiple antibiotic resistance in Salmonella enterica serovar Typhimurium. Antimicrob. Agents Chemother. 44: 3118-21.

Rahman, B.A., Wasfy, M.O., Maksoud, M.A., Hanna, N., Dueger, E., House, B. 2014. Multi-drug resistance and reduced susceptibility to ciprofloxacin among Salmonella enterica serovar Typhi isolates from the Middle East and Central Asia. New Microbe and New Infect. 2: 8892.

Robicsek, A., Strahilevitz, J., Sahm, D.F., Jacoby, G.A., Hooper, D.C.2006. qnr prevalence in ceftazidime-resistant
Enterobacteriaceae isolates fromthe United States. Antimicrob Agents Chemother 50:2872-2874.

Van den Bogaard, A.E., Stobberingh, E.E.1999. Antibiotic usage in animals: impact on bacterial resistance and public health. Drugs 58:589-607.

Winokur, P.L., Brueggemann, A., DeSalvo, D.L., Hoffmann, L., Apley, M. D., Uhlenhopp, E.K., Pfaller, M.A., Doern, G.V.2000. Animal and human multidrug-resistant, cephalosporinresistant Salmonella isolates expressing a plasmid-mediated CMY-2 AmpC beta-lactamase. Antimicrob. Agents Chemother. 44:2777-2783.

Younis Emad, E., Ashraf M. Ahmed, Sabry, A., El-Khodery, Salama, A. Osman, Yasser, F.I. El-Naker.2009. Molecular screening and risk factors of enterotoxigenic Escherichia coli and Salmonella spp. in diarrheic neonatal calves in Egypt. Research in Veterinary Science 87:373-379. 